\title{
Understanding the Experiences and Needs of Mainstream Teachers of ESL Students: Reflections from a Secondary Social Studies Teacher
}

\author{
Yan Wang, Joyce Many, and Larry Krumenaker
}

This case study addressed issues of ESL mainstreaming by examining a teacher's experiences and needs in teaching a social studies class where ESL students were mainstreamed. Extended observations, semistructured interviews, and documentary analysis served to unravel classroom dynamics, showing that the teacher modified various aspects of teaching to accommodate the needs of ESL students, which facilitated their access to the content, but at the same time created problems that had not been examined or predicted by past research. This study exposes the dilemma of providing comprehensible instruction to ESL students and highlights the role of differentiated instruction in diverse mainstream classrooms and the place of students' first languages in learning academic content.

Cette étude de cas porte sur l'intégration des élèves en ALS en examinant les expériences d'un enseignant d'un cours d'études sociales où étaient intégrés des élèves en ALS. Des observations prolongées, des entrevues semistructurées et une analyse documentaire ont permis de mieux comprendre la dynamique en salle de classe. Cette recherche à révéler que l'enseignant modifiait divers aspects de son enseignement pour répondre aux besoins des élèves en ALS, ce qui facilitait leur accès au contenu, mais qui créait en même temps des problèmes que la recherche antérieure n'avait pas évoqués ou prédits. D'une part, cette étude expose le dilemme découlant du besoin de fournir aux élèves en ALS un contenu qu'ils comprennent et, d'autre part, souligne à la fois le rôle de l'enseignement différentiel dans diverses classes ordinaires et celui de la langue maternelle des élèves dans leur apprentissage du contenu académique.

\section{Introduction}

Secondary ESL (English as a second language) students are typically placed in general education classrooms to receive content-area instruction alongside native English-speaking students (Byrnes, Kiger, \& Manning, 1997; Clair, 1995; Harklau, 1994; Merino, 1999; Penfield, 1987). Mainstreaming-immersing language-minority immigrant students in all-English curricula with or without specialized support-is a common practice in United States public schools at the present time (Harklau) and is a visible trend for the future 
(Harper \& Platt, 1998; Youngs \& Youngs, 2001). The move to early mainstreaming as a strategy for cutting educational costs is also playing by the rules of equitable access and opportunities. Access to the regular curriculum, integration with language-majority students, and an authentic context for learning academic English (Clegg, 1996) all make mainstreaming appealing as an instructional program model. On the other hand, disadvantages associated with the accelerated pace at which ESL students are placed in such settings are presumably to be offset by the good inclusionary strategies and differentiated instruction that would be provided.

In reality, however, even given the best of all that we are led to believe would create the ideal situation, ESL students are still failing. Adger and Peyton (1999) and Valdés (1998) noted higher than average dropout rates among immigrant students in high school. Waggoner's (1999) nationwide study of new immigrant students in the US aged 14 to 19 showed that one in five foreign-born minority-L1 students was a dropout, whereas the dropout rate among monolingual English-speaking natives was one in 12. In New York state, 32\% of LEP (limited English proficiency) students dropped out of high school in 2001 after the state began to require passing the academically demanding Regents exams for high school graduation (Crawford, 2004); typically, ESL students who have remained in school are placed in low-track, academically less demanding classes (Harklau, 1994).

The above data suggest that ESL students do not seem to flourish in general classroom settings (Duff, 2001; Harklau, 1994) and that mainstreaming, as the solution proposed a decade or so ago, has not been a panacea. Research in TESOL has begun to study the mainstream learning environment to identify issues facing ESL students and their experiences and needs in advancing through mainstream curricula. The mainstream puzzle, however, is not likely to be fully solved without an understanding of what mainstream teachers experience in such settings and the kinds of challenges that they encounter. Mainstream-content teachers are by far the largest group of educators involved in teaching ESL students (Merino, 1999), but their experiences and perceptions thereof are little known or investigated, other than research showing that they are on the whole inadequately prepared to teach ESL students (Byrnes et al., 1997; Clair, 1995; Harklau, 1994; Merino, 1999; Penfield, 1987). This article presents a study that addressed this gap in the literature, with the view that understanding teachers' experiences and needs can complement information from earlier research on secondary mainstream classes that focused on students, thus helping to untangle the complexity involved in mainstreaming and to unravel the multifacets of the mainstream picture.

In what follows, we summarize theories and studies that looked into the special needs of ESL students and the classroom conditions conducive to their learning that were provided by best practices such as inclusive 
strategies and differentiated instruction. We then review research on specific challenges that mainstreaming has posed for ESL students and up-to-date information about content teachers of ESL students. We then report an ethnographic study conducted at a US secondary school that tapped into the experiences of a secondary school teacher in a social studies course with mainstreamed ESL students, focusing on the effect of ESL mainstreaming on the teacher and his needs arising from working in such a context.

\section{Language Needs}

What do ESL students need in order to succeed in the mainstream? First and foremost, as limited-English-speakers dealing with all-English curricula, they need a grasp of English sufficient to learn the content. Their linguistic needs are twofold. Cummins (1980) distinguishes the kind of language needed for everyday life, which he refers to as basic interpersonal communication skills (BICS), from language necessary for learning academic material such as social studies or science, which he refers to as cognitive academic language proficiency (CALP). CALP is cognitively more demanding and linguistically more complex than BICS, and therefore takes a much longer time for students to develop.

To develop social and academic English, ESL learners need to receive comprehensible input, that is, the kind of language input addressed to their current states of proficiency but at a slightly higher level (Krashen, 1985). They also need plentiful interactions with more advanced English-speakers, from whom they acquire the language through the negotiation of meaning (Long, 1996). In particular, they need opportunities for L2 production, oral or written, which is necessary for learners to develop native-like accuracy (Swain, 1985).

The Place of the First Language (L1)

Although exclusive agreement on the role of the L1 in the process of secondlanguage (L2) acquisition and academic learning in the L2 has not been reached, the TESOL field now is inclined toward a positive view of the L1 in this respect. In Roessingh's (2004) review of effective school literature on ESL programs, most of the studies stressed the importance of the L1 in developing the L2. Evidence elsewhere supports the view that L1 reading and writing skills contribute to L2 literacy development (Peregoy \& Boyle, 2005). With older ESL students who are well schooled in their home countries, conceptual knowledge developed in their L1s is readily transferred to an L2 context. These transferences are made possible by what Cummins (1982) refers to as Common Underlying Proficiency (CUP): a deeper cognitive and linguistic proficiency common across various languages. 


\section{Inclusive Strategies}

ESL programs have historically played the role of meeting students' needs for social interpersonal English. They have been criticized, however, for failing to develop ESL learners' academic English and for isolating them from regular school curricula and native English-speaking students. Mainstream-content classes, on the other hand, may offer opportunities that ESL programs lack. The question remains as to if by mere physical presence in the mainstream, ESL learners can reap the advantages that such settings potentially provide.

Inclusive education as a philosophy and practice arises from special education, which involves placement of students with disabilities in the general education setting, with the goal for them to be "full members of their schools and classroom groups" (Janney \& Snell, 2006, p. 215). To achieve this objective, teachers need to make instructional adaptations in a variety of ways, with the appropriateness of such adaptations judged in large measure by the extent to which they facilitate students' "social and instructional participation in class activities" (p. 216).

ESL mainstreaming, an instructional program model to serve another special-needs population, has parallels with special education inclusion. In the light of what inclusion means in special education, inclusive education for ESL students should go beyond mere placement and aim for students' participation in and membership of the mainstream community. A number of inclusive strategies have been developed in the context of ESL mainstreaming to integrate language and content instruction (L \& C integration strategies) so that ESL learners can gain access to the mainstream curriculum and successfully learn the content. Past research has identified linguistic features of various academic disciplines and their associated types of discourse (Chamot \& O'Malley, 1994): effective L \& C instruction draws on such knowledge and deals implicitly or explicitly with language forms such as lexical items, syntactic structures, and rhetorical styles of particular subjects. Such approaches also highlight linguistic and content scaffolding in other ways, for example, by providing visual support and addressing gaps in prior knowledge (cultural and content). Furthermore, effective school literature identifies group work, interactive activities, modification of language input, and other such tactics as effective L \& C strategies (Roessingh, 2004).

Social studies poses special challenges for secondary ESL students (Duff, 2001): the nature of the content and the discourse type demand a high level of language proficiency in both receptive and productive modes. Classroom activities and tasks involve linguistically and cognitively complex language functions such as analyzing, comparing and contrasting, taking multiple perspectives, critical thinking, and making judgments (Chamot \& O'Malley, 1994). To participate successfully in the social studies curriculum, students must have a certain amount of social, cultural, and geographical background 
knowledge (Duff). Inclusive strategies, therefore, appear especially critical if ESL learners are to benefit from being placed in mainstream social studies classes.

\section{Differentiated Instruction}

One evident consequence of ESL mainstreaming is increased diversity of the student population in the general education setting, a situation that calls for differentiated instruction, an approach that meets students where they are and addresses their varying needs with "the intent ... maximize each student's growth and individual success" (Hall, 2002, p. 2). According to Tomlinson and Allan (2002), all elements of instruction-content, process, and product-can be differentiated in the light of student differences in readiness levels, interests, and learning profiles (such as students' cultural background and learning styles). In mainstream classes with ESL students, the learning profile should include students' English proficiency levels as well. When differentiating content, the core content (concepts, principles, attitudes, and skills) remains the same although students' access to it is differentiated through, for example, texts at multiple reading levels, a variety of instructional media (texts, computer programs, tapes), and so forth. Process can be differentiated by means of diversifying learning activities according to formats, levels of difficulty, amount of teacher and peer support, and students' interests. Products are differentiated by allowing students to demonstrate their learning in a variety of ways, using alternative assessment among others. Differentiation at the level of content, process, and products can also include flexible grouping and tiered activities, as well as flexibility in the use of time, materials, modes of teaching, and so forth.

\section{Past Research on ESL Mainstreaming}

In the light of the theories and research on the needs of ESL students and best practices in educating them, we turn our attention to what the literature reveals about the mainstream classroom in reality such as the extent to which ESL students' needs are met and that best practices are actually present in such settings.

An increasing number of studies have examined the mainstream learning context for ESL learners (Clair, 1995; Duff, 2001; Gunderson, 2000; Harklau, 1994; Harper \& Platt, 1998; Kanno \& Applebaum, 1995; Mohan, 2001). These studies typically investigated how the students fared in such settings and identified problems and challenges that they encountered in gaining access to the academic curriculum, in continuing to develop their English-language skills, and in interacting with native English-speaking students, with the general conclusion that mainstreaming had not been effective in meeting the linguistic, academic, or social needs of ESL students. 
In a two-year ethnographic study on mainstreamed ESL students in two grade 10 social studies classes in a Canadian secondary school, Duff (2001) noted that regular social studies instructional activities and learning tasks such as perspective-taking, narrating, criticizing, open discussions, and structured debates although effective and engaging for native English-speaking students, posed great challenges for ESL learners because the latter lacked the level of language proficiency, pop-culture knowledge, social interactional skills, and confidence necessary for participation, and because L \& C integration strategies that could have assisted the students such as a slower pace of speaking, visual aids, and individual attention were largely absent. The two teachers, well trained and effective in teaching social studies to native English-speakers, did not exhibit a comparable level of effectiveness with the non-native students in the same settings.

Similar findings were reported in Harklau's three-year study (1994) conducted in a US high school, which showed that L \& C integration strategies were not provided in mainstream classes to make input comprehensible for ESL learners. Few opportunities existed in such settings for students to engage in extended oral interactions or in writing, or to continue language development through means such as teachers' feedback on their writing or other feedback addressed particularly to their needs. In addition, ESL students were not able to take advantage of the opportunities provided by mainstreaming to socialize with their native counterparts.

Research on ESL mainstreaming has typically focused on ESL students and portrayed mainstream teachers as unresponsive to and unable to account for these students' needs. Only a handful of studies have been conducted with a focus on mainstream-content teachers. These studies typically looked at teachers' attitudes toward ESL students and associated contextual variables (Byrnes et al., 1997; Penfield, 1987; Youngs \& Youngs, 2001). Teacher preparation and professional development are another issue that has been investigated (Clair, 1995; Clair \& Adger, 1999; Merino, 1999). How mainstreaming has affected mainstream teachers and what their experiences are in such settings have largely been overlooked and, therefore, constitute the focus of the current study.

\section{Methodology}

\section{Context of the Study}

The research site for this study was Central High School (pseudonym), a racially diverse secondary school with a relatively large ESL population in a metropolitan area in the southeast US. The students in the school spoke at least 55 languages and came from approximately 65 countries. During the year 2002-2003, 69\% of the nearly 1,000 students were limited English speakers. The school offered two English as a second language programs, 
which served approximately 340 students. This study defined ESL students as those who were receiving instruction from the two programs.

The study was conducted in Tom's grade 9 social studies class in the Central High School. Tom (all names are pseudonyms) was a veteran teacher who had taught social studies there for seven years. He was drawn to the classroom by his passion for teaching, "I just fell in love with it. I love to teach. I love these subjects ... I like young people." His devotion was evident in his efforts to secure useful materials for students. For example, with his own money he had purchased a cabinet for students to use, as well as a scanner for copying and printing materials, and he wrote a grant proposal to obtain globes. His classroom housed a rich array of instructional and technological resources such as reference books in both English and Spanish, atlases, encyclopedias (both in bound copies and on CD-ROM), and two computers, one of which had been donated by his wife. When the school system failed to purchase the CD-ROM that accompanied the text adopted for his course, Tom purchased the multimedia disk using his own funds.

Tom had attempted to learn Spanish, the primary language for most of his students, using Spanish for Educators (Harvey, 1998), a book on conversational Spanish for teachers to use when communicating with Hispanic students in matters related to classroom instruction.

\section{The Students}

Tom's classes included a majority of students who spoke Spanish as their first language. In the grade 9 class under study, Spanish was the major first language although other languages were also represented.

Approximately half the students each semester qualified for ESL instruction. The rest of the non-native students varied from those who had just left the ESL programs and who still had limited English proficiency, to those who had come to the US at a young age and were quite fluent in English. Some of the non-native students had considerable gaps in their past schooling, as Tom noted,

We've got problems with ESL students because of language, but also because a lot of ESL students are way behind in their educational progression in their own country. We've got kids here who are 16 who stopped school in the third grade in Guatemala.

On another occasion, Tom extended this observation to students' knowledge of geography in particular, stating, "A lot of them come from other countries and they don't know anything about how to read maps, or charts, or graphs."

However, although such gaps did exist in some ESL students' educational experiences, others in this population at the school included some who 
Table 1

First Languages of Students in Tom's Social Studies Class

\begin{tabular}{|c|c|c|}
\hline \multirow[t]{2}{*}{ First language } & \multicolumn{2}{|c|}{ Number of students } \\
\hline & $\begin{array}{c}\text { Fall semester } \\
\text { (World geography) }\end{array}$ & $\begin{array}{l}\text { Spring semester } \\
\text { (Civics) }\end{array}$ \\
\hline Bengali & 1 & 1 \\
\hline English & 5 & 10 \\
\hline Serbo-Croatian & 1 & 1 \\
\hline Spanish & 19 & 15 \\
\hline Urdu & 1 & 1 \\
\hline Vietnamese & 1 & 1 \\
\hline $\begin{array}{l}\text { Total Students } \\
\text { (ESL Students) }\end{array}$ & $\begin{array}{c}28 \\
(10-12)\end{array}$ & $\begin{array}{c}29 \\
(11-13)\end{array}$ \\
\hline
\end{tabular}

exhibited advanced or even exceptional capabilities in their native languages.

Mobility was another notable characteristic of Tom's students. When the semester started, Tom had 90 students across all his classes. As the semester progressed, 50 more students came, and 10 left. This transience was typical among immigrant students, especially Hispanic students from Mexico and Central America. They were absent from school when their families traveled back to their home countries for vacations or holidays. The instability of jobs held by the parents was another cause of frequent moves by the families. About one third of the ESL student participants in this study indicated to us a possibility of not coming back to the same school in the following semester because their parents might get a new job or their families might move for other reasons.

\section{Data Collection and Analysis}

This article focuses on Tom, the teacher of the grade 9 social studies class at Central High School. Data collection occurred in this class beginning in October 2003 and continued through May 2004. The primary researcher (Yan Wang) compiled extensive field notes documenting classroom activities through 120 hour-long observations. Given the exploratory nature of the study (to render a truthful representation of the classroom in its regular state), she tried not to intervene in any of the class activities, but was present merely as an observer. In addition to observations, she conducted six formal interviews with Tom each lasting 30 to 80 minutes and had countless informal conversations with him throughout the year.

Although the case study developed in this research focused on the teacher, similar and nearly concurrent conversations were held with students 
from the class, including both native and non-native English-speakers, to learn their views and experiences about studying in this mainstream social studies class. For students to participate in the study, both they and their parents were asked to read and sign the Consent Form, which was also translated into Spanish for those parents who did not read English.

All the semistructured interviews were tape-recorded and transcribed verbatim. Furthermore, lesson plans, instructional materials, and samples of students' work were collected and examined.

Data analysis began with initial data collection using the coding methods of Strauss and Corbin (1998). Throughout the process of data analysis, checks were conducted to verify the credibility of interpretations. As the primary researcher collected and analyzed data, data collection procedures and interpretations were shared and discussed with the research team members, who offered reflection and critical analysis of emerging categories, of patterns across categories, and of methodological decisions. Emergent themes were also checked and confirmed across multiple data sources: field notes, interview transcriptions, lesson plans, instructional materials, and samples of student work.

\section{Findings}

Tom's experiences in this grade 9 social studies class, after being pieced together through data from different sources, revealed that mainstreaming had a significant effect on him. He admitted that he would teach differently in a classroom with all native English-speakers: "I would be a very different kind of teacher." The effect was seen mainly in the differentiated instruction that he provided and the inclusive strategies that he used. Working in such a context gave rise to needs that Tom expressed mainly through his view of the role of students' L1 in their learning.

\section{Differentiated Instruction}

Tom's class was diverse, which was notably seen in students' varying abilities in English (native English-speakers versus non-native ones, as well as discrepancies in English proficiencies among the latter), and which was also evident in students' varying readiness levels in social studies, general academic skills (such as analytical thinking), and literacy skills in the L1. The instruction provided by Tom showed certain features of differentiation in responding to such a diverse classroom.

Multiple ways for students to gain access to the content. As described in the methods section, Tom's classroom was filled with a wide range of instructional materials and technology resources such as numerous maps, audios, videos, films, and computer multimedia programs, by which students with varied learning styles and levels of English could find their way to access the content. When taping TV programs containing social studies content, Tom 
set the equipment such that the subtitles would appear. When he played the videos in the classroom, students with limited English were able to listen at the same time as they read the captions. And Tom especially considered students' linguistic needs when selecting written materials for instruction. We noted that some of the materials in his classroom were bilingual. For example, Tom had maps and an Atlas of World History in both English and Spanish, and he subscribed for a year to the National Geographic in the two languages so that both English-L1 and Spanish-L1 students would benefit.

Assessment. In assessing students for grades, Tom emphasized knowledge instead of language form. He gave a combination of open-book and closedbook tests. The use of dictionaries was always allowed. "I give them grades for the amount of work they do, and then I give them open-book tests where they can use the book and they can help each other most of the time." When students did not finish a test in class, they were allowed to continue working on it at home because "they're not capable yet in reading and writing at a level sufficient to pass the kind of test we normally give. They don't deserve to fail."

Small class size. In terms of his working needs in such a setting, Tom felt that limiting the class size would significantly improve teachers' abilities to work effectively with ESL students. Although a small class size would facilitate teaching and learning in any setting, Tom felt it was especially beneficial in classrooms that had relatively large numbers of limited English-speakers: "I would have more time to target different materials to different groups and work with the ESL students, more time pairing them, more time pairing them at their competency level."

\section{Inclusive Strategies and Associated Challenges}

In this social studies class with ESL students mainstreamed, we noted that in various elements of instruction Tom employed a number of strategies particularly designed to accommodate these students and to enable them to participate and learn. These strategies, however, resulted in mixed outcomes.

Modifications made to content and materials. Because of non-native students' limited English and the gaps in their academic backgrounds, Tom had to slow his pace of delivery. As a result, less content was covered: "I am probably not going to cover about four or five chapters that I would cover in a normal semester with English-speaking students." Sometimes Tom tried to cover a good deal of information, but in a shallow way rather than in the more thorough manner that he might otherwise have adopted. "In geography, because we cover a lot, we move more quickly, and so sometimes I have to skip every third chapter, just to be able to hit the important chapters." Tom explained, "They can't read as quickly." Tom also had to cut out additional reading and more in-depth investigation of issues related to the course content: "So it's fast. It's very shallow. It's limited." 
Inclusive strategies were also reflected in the reading levels of the materials that Tom chose for his grade 9 class:

I cannot use some of the more sophisticated written materials that require higher-level English language skills. So I'm using more materials that I think are more probably rated, in terms of grade level, at anywhere from around the fifth or sixth grade, late elementary school in terms of the complexity of the English.

When asked what he would do if given a class of all native English-speaking students with good reading skills, he said, "I would use more sophisticated materials. The reading levels would be more difficult. In 11th- and 12thgrade classes, I would be able to use some college materials."

Instructional scaffolding. For the kind of class activities that required relatively high levels of language such as group presentations, Tom provided close scaffolding for students with limited English. Because of inaccurate pronunciation and other problems with the language, ESL students usually lacked confidence in front of the class, and the audience found their speech difficult to understand. Most of the time, Tom would stand by the presenting group and help with pronunciation and vocabulary. He would also explain to the class what the group had presented. Sometimes he would give a brief summary and then ask questions. Other times he would stop the presentation and ask the class questions in order to draw back their wandering attention.

Language scaffolding was also provided through grouping strategies to accommodate students who were struggling with English. Bilingual groups were frequently seen in this social studies class. Students did a great portion of their work in such teams. This procedure allowed students fluent in both Spanish and English to use Spanish as a way to scaffold new students' efforts in conducting the work.

Integrating content and language. Tom's efforts in integrating content and language instruction were seen in card-playing activities where non-native students had opportunities to learn English from socializing with their native English-speaking classmates and at the same time learn academic content from playing with cards that showed all 50 states and included knowledge about Native Americans.

Format and scope of students' work. Tom adapted the format and scope of the students' work that he would assign in order to accommodate the limited English proficiencies of his ESL students. For example, he did not typically have students do the kind of work that required advanced language skills or extended writing.

In the textbook, there are some assignments, some pages in the textbook that I don't assign because the language is too complex. For example, in the civics book, there are some stories about Supreme Court cases. And 
when we study the Constitution, I don't ask them to read the actual language of the Constitution.

Examination of collected students' work showed that the typical formats of assignments given by Tom were answering questions in the textbook, paragraph writing, and short essays. Tom said,

I never assign anything that's more than two or three pages long, and I don't expect essay form because these kids don't even know what essay means. I don't have the time in social studies class to teach it. You can see that even some of the most basic vocabulary is absent.

Tom asked students to write a research paper about once a month. The students would have to use resource books, atlases, and encyclopedias, reflecting his emphasis on research skills. However, according to Tom, such assignments still entailed relatively low academic demands compared with work that would be required of a class of all native English-speaking middleclass students.

The collected students' work and interview data further revealed that with adaptations made on the part of the teacher, students with limited English found ways to do most of the assignments. They learned to locate and copy answers from the textbook; as Mary told us, "Like, I go through the back of the book to the index, and I try to get the main, the basic thing about the question, and I'll go and look in the book, and I'll find it." Jerry used a similar strategy: "Go through the book and copy it [the answer]." When asked about how she liked the work assigned by Tom, Cathy replied, "The matching is easy but the questions, some of them are hard," because "I can't find it [the answer] in the book."

However, the kind of work that involved critical thinking or extensive reading or writing was still mostly unmanageable. Jerry said, "I can find the answers but critical thinking, I don't know how," and he continued, "it's like, think, thinking, don't see it in the book."

Effect on native students in the same class. The instructional modifications made by Tom seemed to have succeeded in integrating ESL students into the mainstream curriculum. The non-native students interviewed for this study, although struggling with comprehending the textbook and with writing, understood Tom pretty well in class, as testified by Sunny:

I'm really bad at social studies, things like that, history classes, but the way [Tom] teach it, the way he say it, the way he describing the things, he has his own little mind, that helps. That's the only reason I get most

of the stuff in the class. That's how I learn.

On the other hand, the native students in the class interviewed did not feel that the instruction was challenging enough in general, although they 
saw the benefit of some of the instructional strategies in refreshing or reviewing past learning; as Katherine commented,

I wouldn't mind some ESOL students being in there ... but then I don't want them to go a slower speed, I want to be able to work the whole period, and be busy the whole period, and not realize it. Like when I sit there for thirty minutes, the little hand is going by so slow. I just stare at the clock, and it's not fun.

\section{The Role of the L1}

All Tom's recommendations for improving ESL students' learning in mixed classrooms like his own were about a central idea of capitalizing on students' first languages. The languages in which students were proficient and literate were also seen as providing content teachers with the kind of assistance in all elements of instruction that they needed to improve their pedagogical success in such settings.

Students' L1 in instruction and learning. Tom saw the need for students with limited English to learn the content in their primary languages. This stemmed not only from his personal philosophy about the status of English versus other languages, but also from a practical concern. He said,

When we get a student from a foreign country who just got here, by the time they learn English well enough to understand the content, they've already missed two years of content. They have to take the end-of-the-course tests at the end of the actual course when they still don't actually speak English, and they're not allowed to use a dictionary on the test, and they're taking a test in English on material in English that they never understood in the first place or they understood only $10 \%$ of it.

Tom repeatedly articulated a pressing need for materials written in students' primary languages and strongly recommended that teachers have the freedom and support to make use of these languages in teaching. "I would like a budget under my control to buy materials in foreign languages ... and a small budget for software and the freedom to install foreign-language software I know about." However, the reality was that "I don't have the money to buy materials, very many materials, in foreign languages. I know how to find it, and I could probably get materials from Mexico, from the government, from the consulate." In addition to materials, Tom perceived it as beneficial for ESL students to do their work and be graded in their native languages.

Both Tom and his non-native students emphasized the benefit of having bilingual speakers in mainstream classes, students who were fluent in both English and the native languages of new ESL students. This would allow facilitation of learning for the newcomers by having peers translate class 
content and assignments and by having students support one another as they worked together in groups.

Other solutions that Tom suggested for more effective mainstreaming included team-teaching with Spanish-speaking teachers and having twoway bilingual classes. He said,

I'm really impressed by some of the California school districts now that are doing bilingual, two-way education, and they teach the

English-speakers Spanish and the Spanish-speakers English, but they all get the content in their own languages.

Administrative support. In the light of the value of students' first languages, Tom articulated the need for greater administrative support either to hire bilingual teachers or to support inservice teachers' in learning a second language. He saw the importance of having content teachers who spoke English as well as the home languages of the limited-English-speaking students, especially teachers bilingual in English and Spanish, given the large number of Hispanic students in the school. One option was for Englishmonolingual teachers to learn Spanish by being provided with monetary expenses and rewarded for their efforts through salary compensation or credits for recertification. The other means was for schools to hire more Spanish-speaking teachers. "I think it's just outrageous that we have so few Spanish-speaking teachers.... It wouldn't be that hard to hire teachers from Mexico who do speak Spanish."

\section{Discussion}

Unlike mainstream teachers reported in earlier studies (Duff, 2001; Harklau, 1994), Tom modified various aspects of his teaching in the light of the needs of his ESL students. Although he had not received any formal ESL training, many of the modifications were appropriate, consistent with what is recommended by research on L \& C integration, and in line with good principles for inclusive education. For example, his instruction emphasized cooperative learning and peer teaching, principles underlying the formation of bilingual groups frequently seen in his classroom. Lectures and other oral instructions were typically accompanied by visual aids, showing his understanding that ESL students needed multiple chances to access information. Providing bilingual reading materials and assuring close scaffolding during students' presentations were additional examples that demonstrate Tom's awareness of the linguistic challenges that students faced and his efforts to offer comprehensible instruction.

On the other hand, some of Tom's instructional modifications-such as shortening content coverage, selecting reading materials below grade level, and cutting down in-depth investigations-raise questions with respect to the level and scope of the resulting student learning. Such accommodations 
may assist teachers in providing comprehensible instruction and facilitate ESL students' transition to the mainstream, but they can come at the expense of the quality of learning. A second area of concern may arise as researchers and teachers consider the standards by which content teachers evaluate the work of their ESL students and assign grades in order to offer support to learner's continual efforts.

These issues expose the dilemma in which mainstream teachers are likely to be caught when making efforts to include their ESL students through instructional modifications. Without such steps to modify instruction, ESL students are excluded to varying degrees from the mainstream curriculum while being physically present in the classroom; on the other hand, the level of learning brought about by such modified instruction may not be optimum for either ESL or native-speaking students in the same class.

Past research on mainstreaming (Duff, 2001; Harklau, 1994; Harper \& Platt, 1998) described content teachers as unresponsive to ESL students' needs and unable to provide accommodation. The researchers typically attributed the failure of education for ESL students in the mainstream context to a lack of specialized ESL training among content teachers and recommended resolutions in the form of providing them with such training through professional development opportunities of various kinds. The content teacher in the present study, however, did not neglect his ESL students and made conscious efforts to accommodate them. However, another set of issues came up, as described above.

This study points to the possibility that problems associated with mainstreaming arise only partly from a lack of effectively inclusive strategies. Training content teachers in these strategies might lessen, but will not eliminate, the problem. The current research suggests resolutions that may be considered complementary to training content teachers with specialized ESL knowledge. Through team or joint teaching, ESL specialists and content teachers might work collaboratively in the same setting, where the content teacher does not compromise the teaching of the content and the ESL specialist helps non-native students with their special language needs and promotes strategies to access academic content. Meanwhile, with the assistance of bilingual materials when available, ESL students could tap into the depth and complexity of academic subjects through their first languages, thus keeping up with native-speaking students in the content area or at least not falling further behind. In addition, use of bilingual groups may allow more experienced ESL students to facilitate learning for newcomers.

The present study further suggests that inclusive strategies to accommodate the needs of ESL students should not be adopted at the cost of neglecting the needs of the native students alongside them. Whereas past research (Duff, 2001) found that appropriate strategies for teaching academic content to native English-speakers were not necessarily effective for ESL 
students, the current study views the issue from the opposite perspective: the increased diversity in such settings calls for more pervasive use of differentiated instruction, which can diversify content, processes, and products such that both non-native and native students are reached. The teacher under study differentiated certain elements of instruction such as multiple ways for students to access the content through a wide range of media and technology, as well as bilingual books geared to the language needs of both Englishspeaking and Spanish-speaking students, but the differentiation that he provided was still limited. For example, all students were provided with texts at the same (instead of multiple) reading levels, instruction was delivered at the same pace to the whole class (instead of in small groups according to students' readiness levels), and the same formats for assignments were offered, requiring the same academic level (rather than tiered activities or tasks geared to varying ability levels).

Additional implications from the current research came from Tom's recommendations for improving learning for mainstreamed ESL students, which highlighted the place of students' first languages in learning academic content, corresponding to claims made by the effective school literature and Cummins' (1982) CUP: his suggestions went beyond provision of bilingual materials to using students' first languages in various central aspects of teaching and learning such as instruction, completing assignments, and testtaking. Although Clair (1995) criticized teachers' desire for bilingual materials as a search for "quick fixes" (p. 192) to address complex educational issues, the present study acknowledges the benefits of such materials in facilitating the learning of linguistically demanding and cognitively complex high school curricula such as social studies. Even with graphic and other kinds of support, advanced language skills are crucial for concept clarification, thorough understanding of theories, and in-depth investigations of social-historical issues. Without the scaffolding of a language in which they are literate, it is highly unlikely that students will achieve learning at a level commensurate with that of their native counterparts. Most important, it is crucial to note that academic knowledge that is developed in the L1 will not be wasted once students have made transition to the L2 because it is transferable across languages.

However, when using a non-English language as the dominant medium for instruction and for other class activities, pragmatic and legal problems are likely to arise. The debate about bilingual education versus English-only goes beyond the scope of this article. The reality is that some states legally bind bilingual education, which restricts the degree to which US schools are permitted to teach in a language other than English. The district, further, may be liable to discrimination lawsuits from parents of students speaking other language if, for example, a large contingent of Spanish bilingual teachers teach geography and other courses while no Chinese or Vietnamese bilin- 
guals are available for the other students. Given these concerns, ESL students' first languages may only be able to play a role in scaffolding and assistance through the availability of bilingual materials, bilingual groups, and possibly bilingual teachers who would resort to a non-English language only on certain occasions.

\section{Conclusion}

This case study investigated the experiences and needs of a social studies teacher who taught in a setting where both limited English proficiency and native English-speaking students were present. The nuances of his teaching and classroom dynamics were uncovered as the data were collected and analyzed, showing that mainstreaming affected various aspects of his teaching. Unlike content teachers in other studies (Duff, 2001; Harklau, 1994; Harper \& Platt, 1998), this particular teacher responded to the needs of his ESL students by modifying his instruction in various ways, which, however, facilitated ESL students' access to the content at the possible expense of undermining the intellectual complexity of learning and the level of critical thinking, a finding not examined or predicted by past research. Thus it seems improbable that effective strategies for combining language and content instruction, along with training content teachers in these strategies, can alone significantly improve the learning environment for mainstreamed ESL students. This study reemphasizes the complex nature of educating ESL students and the importance of recognizing such complexities. It concludes that in order for mainstreaming to work effectively for both ESL and native English-speaking students, a viable approach should incorporate a range of integrated measures such as training content teachers, team-teaching by ESL specialists and content teachers, differentiated instruction, bilingual materials, and bilingual groups.

\section{The Authors}

Yan Wang was formerly an assistant professor at Georgia State University and now works for the Faculty of Education in the University of Macau, China. Her recent research involves understanding English-language learners in the mainstream classroom.

Joyce Many is a professor and Chair of the Language, Literacy, and Social Studies Education Division in Georgia State University, US. Her research has concentrated on understanding children's literacy processes, factors effecting teacher education students' performance, and the scaffolding processes used to support student learning.

Larry Krumenaker was an ESL and science teacher in a diverse high school with a large ESL population in Georgia. He has just completed his doctorate at the University of Georgia's Department of Mathematics and Science Education.

\section{References}

Adger, C.T., \& Peyton, J.K. (1999). Enhancing the education of immigrant students in secondary school: Structural challenges and directions. In C.J. Faltis \& P.M. Wolfe (Eds.), 
So much to say: Adolescents, bilingualism, and ESL in the secondary school (pp. 205-224). New York: Teachers College Press.

Byrnes, D.A., Kiger, G., \& Manning, M.L. (1997). Teachers' attitudes about language diversity. Teaching and Teacher Education, 13, 637-644.

Chamot, A., \& O'Malley, J. (1994). The CALLA Handbook: Implementing the cognitive academic language learning approach. Reading, MA: Addison-Wesley.

Clair, N. (1995). Mainstream classroom teachers and ESL students. TESOL Quarterly, 29, 189-196.

Clair, N., \& Adger, C.T. (1999). Professional development for teachers in culturally diverse schools. Washington, DC: ERIC Clearinghouse on Languages and Linguistics. (ERIC Document Reproduction No. ED435185)

Clegg, J. (1996). Introduction. In J. Clegg (Ed.), Mainstreaming ESL: Case studies in integrating ESL students into the mainstream curriculum (pp. 1-35). Clevedon, UK: Multilingual Matters.

Crawford, J. (2004). Educating English learners: Language diversity in the classroom (5th ed.). Los Angeles, CA: Bilingual Educational Services.

Cummins, J. (1980). The construct of language proficiency in bilingual education. In J.E. Alatis (Ed.), Georgetown University roundtable on languages and linguistics (pp. 76-93). Washington, DC: Georgetown University Press.

Cummins, J. (1982). Interdependence and bicultural ambivalence: Regarding the pedagogical rationale for bilingual education. Arlington, VA: National Clearinghouse for Bilingual Education. (ERIC Document Reproduction No. ED227683)

Duff, P. (2001). Language, literacy, content, and (pop) culture: Challenges for ESL students in mainstream courses. Canadian Modern Language Review, 58, 103-132.

Gunderson, L. (2000). Voices of the teenage diasporas. Journal of Adolescent and Adult Literacy, $43,692-706$

Hall, T. (2002). Differentiated instruction. Wakefield, MA: National Center on Accessing the General Curriculum. Retrieved January 19, 2007, from: http:/ / www.cast.org/system/galleries/download/ncac/DifInstruc.pdf

Harklau, L. (1994). ESL versus mainstream classes: Contrasting L2 learning environments. TESOL Quarterly, 28, 241-272.

Harper, C., \& Platt, E. (1998). Full inclusion for secondary school ESOL students: Some concerns from Florida. TESOL Journal, 7(5), 30-36.

Harvey, W. (1998). Spanish for educators. New York: Barron's Educational.

Janney, R.E., \& Snell, M.E. (2006). Modifying schoolwork in inclusive classrooms. Theory into Practice, 45, 215-223.

Kanno, Y., \& Applebaum, S.D. (1995). ESL students speak up: Their stories of how we are doing. TESL Canada Journal, 12(2), 32-49.

Krashen, S.D. (1985). The input hypothesis: Issues and implications. New York: Longman.

Long, M. (1996). The role of linguistic environment in second language acquisition. In W.C. Ritchie \& T.K. Bhatia (Eds.), Handbook of second language acquisition (pp. 413-468). San Diego, CA: Academic Press.

Merino, B.J. (1999). Preparing secondary teachers to teach a second language: The case of the United States with a focus on California. In C.J. Faltis \& P.M. Wolfe (Eds.), So much to say (pp. 225-254). New York: Teachers College Press.

Mohan, B. (2001). The second language as a medium of learning. In B. Mohan, C. Leung, \& C. Davison (Eds.), English as a second language in the mainstream (pp. 107-126). New York: Longman/Perason.

Penfield, J. (1987). ESL: The regular classroom teacher's perspective. TESOL Quarterly, 21, 21-39.

Peregoy, S., \& Boyle, O. (2005). Reading, writing, and learning in ESL: A resource book for K-12 teachers (4th ed.). Boston, MA: Pearson Education.

VOL. 25, NO 2, SPRING 2008 
Roessingh, H. (2004). Effective high school ESL programs: A synthesis and meta-analysis. Canadian Modern Language Review, 60, 611 - 636.

Strauss, A., \& Corbin, J. (1998). Basics of qualitative research: Techniques and procedures for developing grounded theory (2nd ed.). Thousand Oaks, CA: Sage.

Swain, M. (1985). Communicative competence: Some roles of comprehensible input and comprehensible output in its development. In S.M. Gass \& C.G. Madden (Eds.), Input in second language acquisition (pp. 235-253). Rowley, MA: Newbury House.

Tomlinson, C.A., \& Allan, S. (2000). Leadership for differentiating schools and classrooms. Retrieved January 28, 2005, from:

http://www.ascd.org/portal/site/ascd/template.chapter/menuitem.

b71d101a2f7c208cdeb3ffdb62108a0c/?chapterMgmtId=a91086b18fcaff00Vgn VCM1000003d01a8c0RCRD

Valdés, G. (1998). The world outside and inside schools: Language and immigrant children. Educational Researcher, 27(6), 4-18.

Waggoner, D. (1999). Who are secondary newcomer and linguistically different youth? In C.J. Faltis \& P.M. Wolfe (Eds.), So much to say (pp. 13-41). New York: Teachers College Press.

Youngs, C.S., \& Youngs, G.A. (2001). Predictors of mainstream teachers' attitudes toward ESL students. TESOL Quarterly, 35, 97-120. 